\title{
Witch Accusations, Rapes and Burnings in South Africa
}

With new different power systems in Africa, the whole concept of learning, authority and power is affected. To have authority means in many cases to have inherent power which exceeds the power of others. So called wizards, wachawi, in Tanzania have been found guilty of killing their victims and taking parts from the bodies to obtain and secure power.

The basic ingredients in the medicines which the wachawi use consists of elements taken from the human body on one hand and parts from animals and trees on the other hand. The parts of the body which are obtainable easily are nails, hair and emission of the body. The shadow of a person is also utilized by taking some of the soil over which the shadow had fallen. Other potent parts such as the sex organs, bone from legs or skin from different parts of the body and the nose or tongue are known to be utilized by the wachawi. (Swantz 1970: 321.)

We have a similar description from the South African lowveld: "Witches manufactured dihlare from herbs, roots, animal fats and human bodily substances. A type of sehlare called sefolane was placed on footpaths, entered the body through the soles of the feet and caused paralysis of the legs. Go kotola was made from the victim's own nails, urine, faeces, hair, or footprints, and was used to influence his or her behaviour." (Niehaus 2001a: 25.) Human blood was used in different ways and in the hands of a witch, it could prevent rain. The magic potion could also make friends fight, lightening strike and animals hurt their owners.

In Zimbabwe, many people would like to have well-paid jobs and nice houses, but, "a person who was successful in these respects could easily be suspected of having made use of uroy $i$ [witchcraft] to reach his or her goals and was... [therefore] likely to live with a fear of becoming a victim of uroyi..." (Dahlin 2000: 179-80).

As far as the social system of the Zulus in the 1930 s is concerned, the belief that human flesh was the most powerful fertiliser was propagated. To do sukula, or sukulaing, was a method of doctoring crops in order to secure abundant harvests: "The medicine is thought to remove all the fer- 
tile soil from the lands of other persons and bring it to the charmed fields, and it is therefore a method of obtaining plenty at the expence of others" (Krige 1936: 193). The deployment of magical means for material ends has intensified in the postcolonial context. "Glimpses of vast wealth are accompanied by a chilling desperation of being left out of the promise of prosperity" (Niehaus 2001b: 202).

Among certain Venda people, any form of success, be it political, commercial or even scholarly, is attributed to the supernatural and not to the individual's own efforts. It is believed that to obtain personal success one needs to make use of magic medicines (muti/mushonga). These potions are made more powerful by the use of human parts, such as the hands, ears, nose, lips, eyes and genitals. The strength of the medicine to be used is further enhanced if the victim is young and virile, and if the parts are removed while the victim is still alive. (Minnaar, Offringa and Payze 1992: 21.)

There are several cases of ritual/medicine murders in present South Africa. "Tendani Victor Lukhwareni who was shot while walking to his home on April 18 this year was a chairperson of the Tshivhase Youth Committee, a committee established to fight against ritual murder cases in the area. He was killed hardly five days after he led a big protest march by the community to the area commissioner's office where they were protesting against the dragging ritual murder cases." (Ndivhuwo 2002.)

When it comes to medicine murders, parts of the human body are often used to secure certain advantages from the ancestors. In April 1988, Sharon Mashige, 18 years old, was attacked while in the company of her friend, who fled. Her body was discovered the next day. The girl's external genital organs were cut off while she was still alive, her left leg was severed at the knee and her left arm at the elbow. She was stabbed several times and thereafter decapitated. The tongue had been removed earlier. And why? Because her father wanted some of her fat for a potion. One of the murderers was to receive payment from the girl's father and they had been instructed to obtain the fat from her body. (Minnaar, Offringa and Payze 1992: 59.)

Hilda Kuper pointed out in her studies of the Swazi, that "Murders for 'doctoring' (so-called ritual murders) still [1980s] take place in Swaziland, and fall into two main situational types: (1) agricultural fertility; (2) personal aggrandizement. The victim, referred to as 'a buck', is innocent of any crime and is killed with as much secrecy as possible... The average Swazi condemns murders committed in self-interest as sorcery, and places the ritual specialist who gives the instructions in a different moral and legal category from the diviner who, in his capacity as a witchfinder, may be responsible for the destruction of people publicly revealed as evildoers. The distinction is not accepted by Western law." (Kuper 1986: 69.) 
Isak Niehaus underlines, that the Ralushai Commission was required to investigate medicine murders, but the report only contains an overview of eight ritual murder cases and makes no recommendations, since the commission chose to emphasise another kind of witchcraft (Niehaus 2001a: 226).

In magic cases in Kenya, when it comes to gaining advantage, the sacrifice of a living person is sometimes supposed to be necessary. Utsai, the intentional use of magic, includes medicines and rituals. It can be directed at people, things, or events and the ritual practitioner (as well as the client who requested the action) can be called mutsai. "In the case of an extraordinary greedy person, the mutsai client or mutsai enacts utsai in order to meet his or her desire to obtain inordinate power or wealth. The main objective of the mutsai and mutsai client is not to harm someone, but they are willing to harm someone (create a victim) in the process of achieving their desire." (Ciekawy 2001: 177.)

There was recently a murder case in London which had much in common with South African medicine murders. The discovery of the body, the nature of the wounds and the way in which the boy was killed "are consistent with those of a ritual homicide as practiced in Africa", said Dr Hendrick Scholtz (a South African expert in ritualistic or witchcraft murders). Police in the United Kingdom are currently considering the possibility that they may be facing the first "muti" murder ever committed there. "Muti" is a South African word that means traditional medicine in general, according to Phillips Stevens, an anthropology professor at the State University of New York at Buffalo; "[b]ut in a modern context, it has come to mean pagan or occult", he added. Muti is medicine used to "bring about a result", but that result can be improving one's health, or fortune, or general prospects. It is always based on the idea of taking energy from another living thing for your own purposes. At times, the energies provided by herbs or animals are enough, although human beings are believed to have the most energy. Children, however, are thought to have the most powerful energy of all. "They have not been contaminated, they have not grown up and used it for adult purposes, so they have not been used up yet", said Stevens. (Chang 2003.)

Medicine murders, black magic and spells, witch-related rituals with tragic consequences can be seen as one set of problems in South Africa. Another set is usually called "politically motivated witch-accusations".

There was a rapid increase in the levels of violence in black communities like Soweto, South Africa, in the 1980s and 1990s. A popular tendency was to speak of a "youth crisis" and a "lost generation". This approach failed to locate the structural and historical problems rooted in apartheid. The political crisis of the mid-80s, followed by the successive states of emergency, have fundamentally disturbed the social cohesion of black town- 
ship communities. It is important to point out that the prolonged political turmoil, combined with the historical underdevelopment of black communities, has had dire consequences for these communities. Political conflict has paralysed the structure of government established under apartheid. It has also reinforced community resentment of the police and local government. At the same time, the state actively undermined alternative structures which sought to replace these illegitimate formations and this was coupled with the detention and elimination of experienced local-level leadership (cf. Mokwena 1991). Furthermore, an investigation of the politics of witch-hunting in South Africa during those years is a task of great analytical complexity. "The witch-hunts of the 1990s are multifaceted social dramas, bearing a variety of meanings for different constituencies, within which political actors compete for influence" (Niehaus 2001a: 157).

Victor Turner wrote that the restoration of peace in a social drama involves a change in social relations: "New power may have been channelled into new authority and old authority lost its legitimacy. Closeness may have become distance and vice versa." (Turner 1992: 92.)

How could social relations change through these ritual burnings of socalled witches in South Africa today? Well, they may place the perpetrators in a new position of power and authority, either through what is seen to be socially useful action or through intimidation. The often very large crowds evident at these events, when women are burned as witches, would suggest that a new sense of closeness and unity is generated. And in fact, those who do not actually partake in the burning may throw stones at the corpse as they depart (De Coning and Fick 1986: 35). If the victim is seen to be the internal enemy, there must be some sense of the reasserted strength of the community.

The youth culture as it is lived by youngsters in the streets of Soweto has three main defining features. First, it is survivalistic, in that it is geared towards the material exploitation of an environment which has limited resources. Secondly, violence is an integral feature of this life. Thirdly, it is a machismo culture based on espousing the attainment of masculinity and male dominance. (Mokwena 1991.) Jacklyn Cock notes that the significance of weapons as emblematic of manliness cuts across ethnic groups in South Africa (Cock 1997: 33). She further argues that during the transition period 1990-94, among Afrikaners and Zulus, identities for men were synonymous with being militaristic (Cock 1997: 34). Under apartheid, black female domestic workers "of whom sexual favours were demanded along with their normal domestic workload" (Cock 1980: 99), found out that the relationship between domestic workers and their employers was intensely paternalistic: "it consigns the worker to a dependent and powerless position and it generates a sense of power and superiority in the employer" (Cock 1980: 100). 
In South Africa, many women agree with the belief, that certain women "ask for it" and they "do not feel it is their place or necessary to help women who are being forced to have sexual relations" (Wojcicki 2000: 392). When it comes to street situations and youth gangs, it is probable that all the guns around "contribute to this unwillingness or perhaps inability to help women who are being attacked" (Wojcicki 2000: 393). But this "acceptability of violence can also be explained by the apartheid and post-apartheid governments' failure to legislate harshly against rape and the continued failure to give rapists harsh sentences and low conviction rates" (Wojcicki 2000: 393). Human Rights Watch also reports that South African women, irrespective of race, complain of mistreatment at the hands of police officers taking statements, prosecutors and magistrates in court, district surgeons and court clerks (Human Rights Watch 1995: 3). Moreover, the South African rape laws define rape as a crime occuring only between a man and a woman and only involving the penetration of the penis into the vagina (it does not include oral or anal penetration or penetration with a foreign object) (Human Rights Watch 1995: 3).

When it comes to witch accusations and necklacing, the crisis in masculinity and the centrality of violence in male identity, might play an important role. Black township youth have been historically marginalized by apartheid, leaving them as alienated outcasts within their own wider society. Black township youths have been historically excluded from the key resources of power and authority in the society. Particularly for young post-adolescent males, this leaves them frustrated, emasculated and generally disempowered; it is a generation of young people who have been actively marginalized and brutalized by society (Wojcicki 2000: 388).

Witchfinding can therefore, in many ways, be understood as an attempt by young males to preempt the mystical power of their elders and the structures of gerontocratic authority, by constituting a kind of masculine "imagined community". "Just as the police and army earlier controlled movement along national highways in search of South African 'spies', 'subversives', and women 'black marketeers', so the diviners, playing upon images of state military prowess, sought to regulate movement within novel ritual space in order to reach out the 'real' internal enemies" (Auslander 1993: 185).

Furthermore, young and old men have quite different ideas about witches. The aged are thought to have secret powers of their own, female entrepreneurs are blamed for the AIDS epidemic and since older females make money through their entrepreneurial activities, they are accused of being witches (Auslander 1993: 177-83). The most common reasons given for the burning of alleged witches are certain political motives, the prevailing political unrest, personal jealousy and envy of those regarded as more successful than others, and revenge or the settling of old scores. Some- 
times someone had the misfortune of running into people leaving a funeral and was therefore accused of being connected to the death of those who were dead.

One example of "witch burning" is the death of Nosipho Zamela in 1985, in the Eastern Cape township of Mlungisi in Queenstown.

Between 1983 and 1986 Mlungisi was in a state of violent turmoil. A consumer boycott of white-owned shops brought the police and army to the township. The Mlungisi Massacre involved the shooting of Mlungisi residents inside a church hall, while they were holding a meeting to receive a report from their leaders of a meeting they had held with authorities of the municipality and with members of the white business community. The Mlungisi leaders were given an ultimatum: the boycott must be called off. The leaders decided to have a meeting about it, at ten o'clock on the same day as the boycott was supposed to end at twelve o'clock. Soon army trucks and personnel surrounded the church were the meeting was held, a voice announced over a loud hailer that the meeting had to disperse within five minutes. The order was ignored. Moments thereafter, teargas was fired into the church and a stampede followed during which people tried to escape. Police vehicles followed the stream of people running, shooting at random with bird shot, teargas and real ammunition. Fourteen people were killed and many injured. Three of the victims were buried two weeks after the incident, and eleven were given a mass burial on December 7,1985. Nosipho Zamela, also a Xhosa, was burned as a witch on the 8th.

On the day when strong emotions were at play in Mlungisi, when the final night vigil for the eleven dead was held, Nosipho Zamela was seen being dropped off from an army truck in front of the house where the vigil was held. Soon afterwards, a rumour started circulating that she was "sleeping with Inkatha", which was a reference to the police who were patrolling the streets of Mlungisi and who were believed to be Zulu-speaking.

The strategies used by the police at the time were very crude, and most were designed to shift the focus from their own brutality to "black-onblack" violence. They were known to set up individuals by driving around with them in the township, and then release them while arresting others, giving the impression that is was these individuals who identified the people arrested.

Nosipho was taken from her home some time during the morning of December 8 by marshals from her street, who were followed by a crowd of about sixty youths. She was confronted with the alleged charge of sleeping with the police, being a bitch and a witch. Most of the morning was spent walking her through the streets and demanding that she identified other women who were supposedly sexually involved with the police. The search for other women yielded nothing and the marshals from the street, who 
were now joined by marshals from other streets, became increasingly angry, accusing her of making fools of them. Many people in the crowd started shouting obscenities at her. Some of the men started poking her with sticks and sjamboks in her vaginal area as they continued to shout at her. Women's voices were also heard accusing her of grooming herself for the benefit of Inkatha and using "blood money" to buy clothes. One of the witnesses remembered a young man who was a marshal saying: "You didn't want to sleep with us, but you made yourself available for Inkatha!"

An argument over how she was going to be punished ensued after a man's voice called out: "She must be burnt!" The marshals from her street argued against the burning of Nosipho, but they were silenced and threatened by a group of marshals from another area. More people gathered on the way and there was singing and toy-toying. They shouted at her: "Let the one who sold her own die" and "Let her fry!" The burning necklace, a tyre soaked in petrol, killed her while the people were singing and dancing doubt. (Gobodo-Madikizela 1999: 106-12.)

According to Isak Niehaus, witch hunting must be understood in the first place as an attempt to eliminate misfortune. "Those who support and organise action against witches therefore perform a valuable social service, and attain political legitimacy. Despite important changes in the forms of witch-beliefs and in patterns of witchcraft accusation, there have been remarkable continuities in its political implications over time." (Niehaus 2001a: 154.)

Procedures are often established to protect those who are accused of practising witchcraft, since the law is against "witch finding". But when people see the authorities protect accused witches, this makes them believe that people occupying powerful positions within the state are using witchcraft for their own purposes. Witchcraft and modern politics are closely related, "state authoritarianism reinforces this link by creating an atmosphere of undeclared competition that makes politics and occult forces hard to distinguish" (Geschiere 1997: 98).

The present situation is a result of the demolition of the apartheid government, widespread rebellions among the youth and marginal elite political movements. The problem is of multiple causation and when it comes to witch accusations, we must evaluate sociocultural change within a matrix of power relationships in (and between) goverments, apartheid and post-apartheid, and society.

Isak Niehaus, who recently wrote about witchcraft and the sexuality of evil in the South African lowveld, suggests that discourses about witchcraft and sexuality should be treated as a resource in micro-political studies in the domestic domain: 
Gossip, derogatory statements, and scandal-provoking stories about unacceptable sexual conduct sanctioned certain moral ideas. These open-ended narratives could be a prime site of resistance... Ordinary people could use rumours and scandals to ridicule and humiliate the reputations of dominant persons who abuse their rights to exercise power... in the lowveld accusations of witchcraft are a hallmark of intra-gender struggles. Insubordinate wives, obstinate daughters-in-law, and elderly infertile woman, as well as vulnerable men fell victim to these accusations. (Niehaus 2002: 38-39.)

According to the Commission on Gender Equality (2000): "Witchcraft violence, which has been prevalent mainly in the Northern Province, has had devastating consequences on those who are accused of being witches, which in most cases are old women in these communities. The results in this regard have been mass murders, displacement and ostracisation of families suspected of being witches."

Violence against women in South Africa is common in all groups, whether we categorize them by race, class or ethnicity. In addition to linking this level of violence with the apartheid regime and resultant poverty, inequality and racism, the effects of militarization on South African society are important in creating stereotypes which link masculinity with violence (Wojcicki 2000: 389).

In KwaMashu, the second largest township outside Durban, a gang called "bhepa span" (from a Zulu word meaning crude sex), focused on raping young girls. In 1995, they gang-raped a local high school teacher while her students looked on. In connection with this, Suzanne LeclercMadlala notes that the high incidence of rape in KwaZulu/Natal might relate to a belief that having sex with a virgin can cure one from the HIV / AIDS virus (Leclerc-Madlala 1997).

In a survey conducted by the Commission of Gender Equality (2000), it is obvious that the problem of violence against women in South Africa is not limited to incidences of gang-rape.

Furthermore, only one out of every 10 boys interviewed in Gauteng schools opposed sexual violence. Janet Maia Wojcicki, who studied sexwork and violence in the "new" South Africa, realized that many South African men compared women with children and rationalized that, in the same way it is necessary to hit a child if he or she misbehaves, a wife also needs to be controlled through discipline and violence (Wojcicki 2000: 388).

According to Anne K. Mager and Steve Mokwena, South African men have been taught to define their power in terms of their ability to impose their will on women (Mager 1996; Mokwena 1991).

Mokwena points out that the increase in township-based youth violence has most notably been accompanied by a dramatic increase in violence that is specifically directed against young women. Whilst it is true that rape, like all forms of male violence against women, is connected to 
the broad socio-cultural milieu which is suffused with beliefs of male dominance, supremacy and aggression, this generalisation does not explain the emergence of the distinct youth subculture of violence known popularly as "jackroll". (Mokwena 1991.)

Jackroll is often committed by roving gangs of armed youths. As a matter of fact, it seems part of the exercise is to be exposed so as to earn respect. Most incidents of jackroll are committed in public places like shebeens, picnic spots, schools, nightclubs and in the streets. It is almost always committed in the open, and the rapists do not make attempts to conceal their identity.

It also seems plausible to argue that jackroll is directly linked to attempts by young males to reassert their power via distorted masculine sexuality. When jackroll first emerged, the victims were carefully selected. Initially many of the victims were those women who were thought to be out of reach because of their class and status. Such women would be called by derogatory names such as "amahaiza" meaning snobs (Mokwena 1991).

South Africa recorded 1,263 rapes in 1979. In 1999 the official annual figure was nearly 50,000, but rape-crisis researchers say only 1 in 35 was reported. Probably there are more than 1.6 million rapes a year - the highest incidence in the world, according to Interpol. (Hawthorne 1999: 1.)

Many women being raped are called witches and it seems like "witch" is an umbrella term for "the evil". In several cases, instead of a gang rape there was a "witch burning". As to why burnings began, Joanna Ball (1994) suggests that the initial rural witch burnings developed in a climate of great social and economic change. There was intense social interaction which had become ill-defined, due to such things as high unemployment, migrant labour and the demise of chiefly authority. This great uncertainty was also to be found in the urban townships in the mid-eighties, which was when the necklace gained notoriety. These "witch hunts", of traitors or murderers or witches, are a means of reasserting communal values. The internal enemy is expunged in an attempt to grasp some form of control over the new uncertainties.

Apart from death from extreme age and minor illnesses, all deaths and occasions of misfortune are believed to be caused ("sent") by some external agent. When the sufferer has neglected religious duties, misfortune is supposed to be caused by the ancestors, but witchcraft attacks comes from "without", therefore the one who suffers is not to blame. "Generally speaking, witches were believed to be women and sorcerers men. This might have been because sorcery involved the actual buying of medicines from a herbalist, while witchcraft could be practised in secret, from within the demure confines of the domestic unit, and thus be more congenial to women. (Hammond-Tooke 1993: 169-70.) 
Witches represent behaviour that deviates from the accepted norms of a society, they are evil and create disharmony in social relationships. To call someone a witch is to say that she is a traitor, that she stands in an antagonistic relationship to the rest of the group. In South Africa, there is a strong connection between the victims of burnings, such as witches and collaborators, in that they are seen to "sell out" at the expense of the community and break its social solidarity. The fact that the initial burnings were to punish witches, supposed to have supernatural forces, and only later came to include collaborators then becomes understandable, as it was only in the mid-eighties that the urban areas became increasingly political and where "collaborating" became another means by which communal values could be betrayed.

A woman involved in the anti-apartheid movement would be frightened to report rape by a "comrade" in "the struggle", because all the other comrades would condemn her as having "sold out" to the racist government (Sharlach 2001: 170). According to Lisa Boswell Sharlach, "from the mid 1980s until the all-race elections of 1994, the intensity of violence was so high that some referred to it as civil war... as the level of ethnic violence in a country increases, so too does the state's role in permitting or perpetrating sexual violence increase" (Sharlach 2001: 165). Other hypotheses are: "As the stigmatization of female rape survivors increases, a state's involvement in permitting and/or perpetrating rape of stigmatized group members increases" and "As the degree to which stigmatized groups coincide with class division, a state's involvement in permitting and/or perpetrating rape of stigmatized group members increases." Through her studies, Sharlach shows that "South Africa during apartheid had both state perpetration of sexual violence and pronounced class inequality" (Sharlach 2001: 180). She has come to the conclusion that "when the leaders declare a state of emergency in a society in which there is a vast socio-economic income gap that corresponds to ethnic divisions, state agents' rape of those belonging to a stigmatized group may follow" (Sharlach 2001: 195).

Michelle Rosenthal, who has examined domestic violence and rapes in South Africa after 1994, writes: "Despite constitutional guarantees of equality in the new democracy, the issue of violence against women continues to be of the gravest importance. The activists who struggle with this issue daily deserve our attention as powerful political agents of change both within South Africa, and beyond, in a transnational feminist dialogue on human rights, democracy and justice." (Rosenthal 2000: 114.)

When Pumla Gobodo-Madikizela made case studies based on interviews with perpetrators of a necklace murder, she found out that "Apartheid strategies were no less violent than those used in the resistance against it. In fact, the strategies used by apartheid were much more organised and systematic, not only in terms of the official arsenal and official structures 
of the police and army... Many writers hid this violence from scrutiny by focusing on anti-apartheid violence, and by doing so, projecting government repressive measures as a legitimate response." (Gobodo-Madikizela 1999: 24.) According to Gobodo-Madikizela, the subtext often reinforces the myth of blacks going on the rampage in mindless unprovoked killing. A necklace incident has to be placed in its proper political context. (GobodoMadikizela 1999: 25.)

While looking at necklace murders, there are two symbols that need to be scrutinized: the notion of the necklace and the consuming of a person by fire. Given that those receiving this punishment are those who have deviated from the social norms of the group, the symbol of the necklace is perhaps associated with ideas such as that presuming the existence of a social community which is important, that it is immoral to act anti-socially and that it will not be tolerated, that communal interests should be placed above individual greed, that social harmony is important. It also conveys a message of what the relationship is to those outside the group. For example, where the youth gain political power through the threat of the necklace, it intimidates those who would oppose them. The necklace defines what behaviour is expected of the community and defines the power relationship. On a broader scale it can define the relationship of the community to the system of apartheid and white supremacy that existed until 1994.

The horror of the separation of the head from the body is perhaps fairly universal, and the burning necklace could be seen as a decapitator in a sense. It is perhaps of some relevance that the "guillotine" (another term for the necklace) portrays this same idea. The term necklace could also have an ironic association. It usually carries positive emotional associations. Necklaces are given as gifts, they are decorative and are normally seen to enhance one's appearance. Also protective medicine is sometimes worn around the neck. For example, the youth gangs in Pietermaritzburg would be given protective medicine from traditional healers, and this could be tied in a small bottle around the neck. With the necklace becoming a burning tyre, there is a direct symbolic reversal of the term which is the more potent because of the strong positive connotations on the one side and the very strong negative connotations on the other. This potency would seem to explain why the term has become so renowned and is used beyond its strict sense (cf. Ball 1994; Sosibo 1992).

Burning symbolises a number of things. It may be associated with the destruction of the soul of the person, thus breaking the link with the ancestors, it may signify the destruction of evil or the purification of society. Obviously, in the physical sense, the victim is unrecognisable after she has been burnt, so there is a visual destruction of the person (cf. Ball 1994). 
But beside all those political reasons, clearly many people in South Africa take witchcraft very seriously. The reality of such beliefs manage and compensate for undeserved misfortune and should therefore not be dismissed as an idiom that masks ulterior motives, and is aimed at intimidating political opponents. On the contrary, witch-hunting must (as Niehaus points out) be understood in the first place as an attempt to eliminate misfortune. Witches have been perceived as threatening people's livelihood in many South African communities for centuries. Witchhunts were aimed at restoring fertility to the land and reaffirmed the solidarity of villagers.

In the post-relocation years, witches were perceived at threatening individuals and individual households. Before 1994, youth gangs exploited public perceptions that the South African government protected witches. According to Niehaus, they gave powerless individuals the necessary public support to accuse neighbours and kin of being witches, and although many elderly people felt intimidated by those gangs, it can be argued that this was a consequence of, rather than a motivating factor for, witch hunting. In making accusations youths sought the public co-operation of village adults, and followed the consensual identification of individuals as witches. (Niehaus 2001a: 154.)

At this level, the ritual "may express deep contradictions in the social or cultural system - all kinds of troubles, uncertainties, conflicts and paradoxes" (Moore and Myerhoff 1977: 16). The witch burnings can be seen as a result of social changes. These were caused by such things as forced resettlement, the gradual erosion of the power of the chiefs, the breakdown of agricultural subsistence and the reliance on migrant wages. Kinship patterns of residence were disrupted, resources became scarce and unemployment increased. The new social relations became uncertain and illdefined (cf. Ball 1994).

In the dramatic encounter between witch accusers and witch accused, all those involved are locked in conflict about "the truth" and about real intentions. The institution in which the drama is now being played out, the New South Africa, is a creation that sees itself as establishing facts and finding law. Apparently open to multivocality and many authentic meanings, the stories about rapes and witch burnings give the victims no real recognition. Internal versions have less validity than outside ones and in the end, all those stories are about something: the suppression of the woman's voice.

\section{References}

\section{Auslander, Mark}

1993 Open the Wombs! The Symbolic Politics of Modern Ngoni Witchfinding. In: Jean Comaroff and John Comaroff (eds), Modernity and Its Malcontents. 
Ritual and Power in Postcolonial Africa; pp. 167-92. Chicago and London: Ball, Joanna

The University of Chicago Press.

1994 The Ritual of the Necklace. Centre for the Study of Violence and Reconciliation, March, 1994.

\section{Chang, Andrew}

2003 Human Sacrifice in London? Mutilated Body Sparks Fears of "Witch Doctors" at Work. www.abcnews.go.com/sections/world/DailyNews / britain020204_muti.html; February 4, 2003.

\section{Ciekawy, Diane}

2001 Utsai as Ethical Discourse: A Critique of Power from Mijikenda in Coastal Kenya. In: George Clement Bond and Diane M. Ciekawy (eds), Witchcraft Dialogues. Anthropological and Philosophical Exchanges; pp. 158-89. Athens: Ohio University Press.

Cock, Jacklyn

1980 Maids and Madams. A Study in the Politics of Exploitation. Johannesburg: Ravan Press.

1997 The feminist challenge to militarism. Agenda 36: 27-39.

The Commission of Gender Equality

2000 Address by the Chairperson at the official launch of the witchcraft roadshows in the Northern Province, 18-25 July 2000. www.cge. org.za; September 11, 2000.

Dahlin, Olov

2000 Zvinorwadza. Being a Patient in the Religious and Medical Plurality of the Mberengwa District, Zimbabwe. Uppsala: Universitetstryckeriet.

De Coning, C, and J. Fick

1986 Menslike Verbrandings: 'n Sosio-Politieke Ondersoek na die Aard en Impak van Kataklismiese Geweld in Suid Afrika. Politikon 31 (1): 22-53.

\section{Geschiere, Peter}

1997 The Modernity of Witchcraft. Politics and the Occult in Postcolonial Africa. Charlottesville: University Press of Virginia.

Gobodo-Madikizela, Pumla

1999 Legacies of Violence: An in-depth analysis of two case studies based on interviews with perpetrators of a "necklace" murder and with Eugene de Kock. Ph.D. thesis, University of Cape Town.

Hammond-Tooke, David

1993 The Roots of Black South Africa. Johannesburg: Jonathan Ball Publishers.

Hawthorne, Peter

1999 An Epidemic of Rapes. Outrage fuels a protest movement in South Africa. Time Magazine, 11 January, 1999.

Human Rights Watch

1995 Violence Against Women in South Africa: State Response to Domestic Violence and Rape. Los Angeles: Human Rights Watch.

Krige, Eileen Jensen

1936 The Social System of the Zulus. London: Longmans, Green and Co.

Kuper, Hilda

1986 The Swazi: A South African Kingdom. New York: Holt, Rinehart and Winston. 


\section{Leclerc-Madlala, Suzanne}

1997 Infect One, Infect All: Zulu Youth Response to the AIDS Epidemic in South Africa. Medical Anthropology 17: 363-80.

\section{Mager, Anne K.}

1996 Sexuality, fertility and male power. Agenda 28: 12-24.

Minnaar, Anthony, Dirkie Offringa, and Catharine Payze

1992 To live in fear. Witchburning and medicine murder in Venda. Pretoria: HSRC.

Mokwena, Steve

1991 The Era of the Jackrollers: Contextualising the Rise of Youth Gangs in Soweto. Johannesburg: University of the Witwatersrand, Centre for the Study of Violence and Reconciliation.

\section{Moore, S., and B. Myerhoff}

1977 Secular Ritual. Assen: Van Gorcum.

\section{Ndivhuwo, Musetha}

2002 We'll create anarchy, warn Tshivhase community. Zoutnet, June 28, 2002.

Niehaus, Isak

2001a Witchcraft, Power and Politics. Exploring the Occult in the South African Lowveld. With Eliazaar Mohlala and Kally Shokane. Capetown and London: David Philip/Pluto Press.

$2001 \mathrm{~b}$ Witchcraft in the new South Africa: from colonial superstition topostcolonial reality? In: Henrietta Moore and Todd Sanders (eds), Magical Interpretations, Material Realities. Modernity, Witchcraft and the Occult in Postcolonial Africa; pp. 184-205. London and New York: Routledge.

2002 Perversion of Power: Witchcraft and the Sexuality of Evil in the South African Lowveld. An unpublished paper. University of Pretoria and Yale University.

Rosenthal, Michelle

2000 Violent Pasts, Democratic Futures: Engendering Cultural Citizenship in the New South Africa. Ph.D. thesis, University of California, Santa Cruz.

Sharlach, Lisa Boswell

2001 Sexual Violence as Political Terror. Ph.D. thesis, University of California.

\section{Sosibo, M. B.}

1992 Healing, Ritual and Violence at Edendale, Pietermaritzburg. Paper presented at the Annual Conference of the Association for Anthropology in Southern Africa, University of Durban-Westville, 16-19 September 1992.

\section{Swantz, Marja-Liisa}

1970 Ritual and Symbol in Transitional Zaramo Society. Lund: Gleerup.

Turner, Victor

1992 The Anthropology of Performance. Baltimore: The Johns Hopkins University Press.

Wojcicki, Janet Maia

2000 Sex-Work, Stigma and Violence in the "New" South Africa: An Ethnographic Study of Sex for Money Exchange in Gauteng Province. Ph.D. thesis, University of California. 